\title{
Skeletal Fluorosis In Relation To Drinking Water, Nutritional Status And Living Habits In Rural Areas Of Maharashtra, India
}

\author{
Varsha Dhurvey ${ }^{1}$, Sonali Dhawas ${ }^{2}$
}

\section{Introduction}

Fluorosis is an endemic disease resulting from excess intake of fluoride (F) through drinking water, food or dentrifices. Skeletal fluorosis is caused by prolonged intake of excessive amounts of fluoride. Endemic skeletal fluorosis is widely prevalent in India and in many countries around the world but it is a major public health problem in some 25 countries in Asia and Africa. ${ }^{1}$ Good nutrition is as important for bone health as it is for general health. The severity of fluoride toxicity depends on the concentration of fluoride in drinking water, daily intake of fluoride, continuity and duration of exposure to fluoride, although the adequate nutrient intakes of calcium, vitamin D, and protein are of critical importance for bone health, phosphorus and certain trace minerals (magnesium, manganese, copper, and zinc) and vitamin $\mathrm{C}$ and $\mathrm{K}$ are also involved in bonehealth. ${ }^{2}$

Although the prevalence of fluorosis in relation to the concentration of $\mathrm{F}$ in drinking water has been widely reported. Studies on the occurrence of fluorosis in relation to other variables such as age, sex, and certain dietary components are also of interest. ${ }^{3-5}$ Because the incidence of fluorosis in relation to nutritional status, use of certain foodstuffs and living habits of subjects has had only limited study, the present investigation was undertaken to determine the relationship of skeletal fluorosis to drinking water, nutritional status, living habits, age, sex and various vices in selected villages of Warora tehsil of Chandrapur district, Maharashtra.

\section{Materials And Methods}

\subsection{Study area - Warora tehsil, Chandrapur district, Maharashtra, India}

The present study was carried out during May 2010 to December 2011 in three villages which were randomly selected from Warora tehsil of Chandrapur district which is one of the endemic district of Maharashtra. The area selected for present study lies in western part of Chandrapur district and located at 20 $14^{\prime} \mathrm{N} 7900^{\prime} \mathrm{E} / 120.28^{\prime} \mathrm{N} 79.00^{\prime} \mathrm{E}$. The climate of the area is extreme type. The summer is very hot and winter is very cool and pleasant. The average annual rainfall is about $1420 \mathrm{~mm}$.

\subsection{Collection and analysis of water samples}

All the presently available ground water samples were collected and the mean fluoride concentration was estimated by the ion analyser method, varied from 0.73 to $2.80 \mathrm{mg} / \mathrm{L}$ compared to the recommended maximum permissible limit of $1.5 \mathrm{mg} / \mathrm{L}$. ${ }^{6}$ Major sources of water for drinking and irrigation were deep wells and hand pumps in the study area.

\subsection{Selection of sample}

A pilot survey of the three villages was undertaken to know the severity of the disease finally one village was purposively selected for further study due to high fluoride concentration in drinking water and presence of patients with clinically defined skeletal fluorosis.All the members in the households were surveyed making a total of 915 subjects of all ages. Skeletal fluorosis was diagnosed by three diagnostic tests. ${ }^{7}$ A questionnaire was designed to collect information regarding names, sex, age, occupation, nutritional status (good, fair, and poor), dietary habits, living habits and clinical symptoms of skeletal fluorosis and all individuals who had lived in the village were included in the study. Before start the study the ethical permission was taken from the department of ethical committee.To record the clinical symptoms of fluorosis a checklist was developed with the help of available literature and in consultation with nutritionist.The symptoms were recorded by personally interviewing each individual of the family.The symptoms were further tabulated and percentages calculated.

Food samples of the study area were collected, homogenised, dried, powdered and analysed for protein, calcium, vitamin $\mathrm{C}$ and fluoride. ${ }^{8}$

\section{Results}

In the three villages of the study area the range of fluoride concentration of the presently available ground water sources (Table1) and total number of study subjects(Table 2). From the data in Table 3 and 4, it is clearly seen that fluoride content of the foodstuffs was higher and in addition to fluoride other major 
constituents of foodstuffs, protein, calcium, and vitamin $\mathrm{C}$ was lower. As seen in Table 5 a high prevalence of skeletal fluorosis was observed from habitual users of black tea and tobacco whereas a relatively very low prevalence of fluorosis was observed among non-users. Clinical symptoms of skeletal fluorosis patients from study area were as shown in Table 6.The prevalence of skeletal fluorosis increased with age (Table 7). Similarly, a high prevalence of skeletal fluorosis (Table 8) was also observed among males than the females. The statistical association between the prevalence of skeletal fluorosis and age $(\mathrm{P}<0.001)$ and $\operatorname{sex}(\mathrm{P}<0.001)$ by Chi-square test were found to be statistically significant.

\section{Discussion}

Over $90 \%$ of the people affected with severe fluorosis belongs to the low socio-economic status and they had generalized nutritional deficiencies. ${ }^{9}$ In the rural areas of the present study, villagers are mostly illiterate and socio-economically backward and poor in the society, majority of the adults involved in agriculture were either farmers or manual labourers and generally drink more water, thereby maximizing their fluoride intake. The present results revealed that the fluoride concentration in the drinking water of the study area was found in the range of 0.73 to $2.83 \mathrm{mg} / \mathrm{L}$. The mean fluoride concentration in drinking water sources ranged from 0.66 to 5 $\mathrm{mg} / \mathrm{L}, 1.0$ to $6.1 \mathrm{mg} / \mathrm{L}$ and 1.3 to $2.7 \mathrm{mg} / \mathrm{L}$ in some villages of Chandrapur district, Maharashtra, ${ }^{10}$ rural tribal areas of Rajasthan, India ${ }^{11}$ and Agastheeswaram Union of Kanyakumari district ${ }^{12}$ as noted earlier.

Due to poor socio-economic condition people used locally grown food grains like wheat, sorghum in the form of roti and sorghum gruel with either chilly chutney or locally grown vegetables like brinjal and tomato. Sorghum containing higher amount of molybdenum favours the absorption and retention in the later stages. ${ }^{13}$ It was observed that fluoride content of food stuffs obtained in the present study was generally higher than fluoride non-endemic areas. ${ }^{14}$ The earlier studies reported high fluoride content in food grains in Dharwad district of Karnataka ${ }^{15}$, as the foods grown in endemic fluorosis areas tend to absorb higher fluoride from the soil and water. ${ }^{16}$

In the present study it was observed that the other major constituents protein, calcium, and vitamin $\mathrm{C}$ along with fluoride content of the food stuffs were lower as compared to nutrition chart. The adequacy of protein and calcium in $\operatorname{diet}^{15}$ and villagers with "poor"nutritional status showed the highest incidence of dental and skeletal fluorosis. ${ }^{11}$ Susceptibility of Indians to fluorosis was claimed to be due to poor nutritional status. ${ }^{17}$ The dietary deficiencies of energy, calcium, ${ }^{18}$ calcium and vitamin $\mathrm{C}^{17}$ were claimed to be the reasons for early on set of fluorosis. In farmers and labourers, the nutritional value of their food is generally very poor and therefore deficiency of vitamins and other dietary components is possible which can decrease or increase fluoride absorption/intoxication. ${ }^{19}$

The substance like black tea and tobacco contain elevated level of fluoride that are additional sources of fluoride which would enhance the body burden fluoride in already affected people. ${ }^{20-23}$ The common beverage consumed in the study area was black tea, and some had also involved in chewing of tobacco. The prevalence of skeletal fluorosis was observed in $19.85 \%$ in habitual tobacco users, and $11.91 \%$ in black tea users. The earlier investigator reported the same in the daily wagers and farmers ${ }^{12}$, skeletal fluorosis $(52.30 \%)^{24}$ and skeletal and dental fluorosis $(40 \%)^{22}$ of the tobacco chewers.

In the present clinical examination it was observed that the most common symptoms joint pain (35.75\%), back pain $(29.01 \%)$ and other symptoms like tingling and numbing of extremities, shoulder pain, neck pain and stiffness are the symptoms of skeletal fluorosis. Earlier investigators found that back pain (68\%), joint pain $(22 \%)^{25}$, pain or stiffness in the backbone and hip (16.2\%) and pain or stiffness in joints and backbone $(15.5 \%)^{24}$ and back pain $(73 \%)$ and neck pain $(34 \%){ }^{26}$ The common symptoms are pain in the neck and back associated with rigidity, joint pains and paraesthesia of the limb. ${ }^{27}$

In the present finding the overall prevalence of skeletal fluorosis cases was found to be $(21.09 \%)$, whereas the results are in agreement with $21 \%{ }^{25}$ and $24.9 \%{ }^{24} \mathrm{As}$ well as the skeletal fluorosis prevalence increased with age, similar result is also found by other investigators. ${ }^{24}$

Skeletal fluorosis was more common in males. ${ }^{24,27}$ In the present study the skeletal fluorosis was more prevalent among males (24.14\%) than females (17.89\%) while this is the first report in association to skeletal fluorosis, and nutritional status and particularly, in Warora tehsil of Chandrapur district of Maharashtra.

\section{Acknowledgement}

The authors acknowledge the help of villagers, Sarpunch and staff of rural PHC of Pijdura, Majara, and Temurda for their co-operation and Ex-head Dr.SabihaWali, Head Dr.Shubhada Jambulkar and faculty members of the Department of Home Science, RTM Nagpur University for analysis of foodstuffs during the conduction of this study.

\section{References}


[1] R. Reddy, Neurology of endemic skeletal fluorosis, Neurology India, 57, 2009, 7-12.

[2] S. P. S.Teotia, and M.Teotia, Nutritional bone disease in Indian population, Indian J Med Res,28, 2008,127 - 219.

[3] S. S. Jolly, B. M. Singh, B. C. Mathur, and K. C. Malhotra, Epidemiological,clinical and biochemical study of endemic dental and skeletal fluorosis in Punjab, British Med J, 4, 1968, 427-29.

[4] V. K. Desai, D. K. Saxena,B. S. Bhavsar, andS. L. Kantharia, Epidemiological study of dental fluorosis in tribals residing near fluorspar mines, Fluoride, 21,1988, 137-41.

[5] S. L. Choubisa, and K, Sompura, Dental fluorosis in tribal villages of Dungarpur district (Rajasthan), Poll Res, 15, 1996, 45-47.

[6] WHO, Guidelines for Drinking-Water Quality, WHO Library Cataloguingin- Publication Data, $4^{\text {th }}$ Ed.,2011.

[7] A. K. Susheela, N. K. Mondal, and A. Singh, Exposure to fluoride in smelter workers in a primary Aluminum industry in India, The International Journal of Occupationaland Environmental Medicine, 4, 2013, 61-72.

[8] R. Raghuramulu, K. M. Nair, andS. Kalyanasundaram, A manual of laboratory techniques. National Institute of Nutrition;2004.

[9] S. P. S. Teotia, Environmental fluoride and metabolic bone disease, an epidemiological study (Fluoride and nutrient interaction), Fluoride, 17, 2011, 37-41.

[10] S. Dhawas, V. Dhurvey, J. Kodate, and R. Urkude, An epidemiological study of skeletal fluorosis in some villages of Chandrapur district, Maharashtra,India, JERAD, 7,2013, 1679-1683.

[11] S. L. Choubisa, L. Choubisa, andD. Choubisa, Osteo- dental fluorosis in relation to nutritional status, living habits, and occupation in rural tribal areas of Rajasthan, India, Fluoride, 42, 2009, 210-15.

[12] A. A. Joshi Raj, and V. Umayorubhagan, Fluorosis in relation to nutrition, fluoride in drinking water and socio economic background in Agastheswaram Union, India, IJIET, 2, 2013, 337-39.

[13] G. K. Stookey, andJ. C. Muhler, Effect of molybdenum on fluoride retention in the rat,ProcScoExpBiol Med, 1962,109 - 268.

[14] S. R. Sengupta, andB. Pal, Iodine and fluoride content of foodstuffs, The Ind. J. Nutr.Dietet,8,1971,66.

[15] P. Bharati, andM. Rao, Epidemiology of fluorosis in Dharwad district, Karnataka, J. Hum. Ecol, 14, 2003, 37-42.

[16] J. B. Batra, A. N. Vispute, Deshmukh, andS. Vali, Contribution from rock,soil and ground water to fluoride content of foodstuffs grown in some selected villages of BhadrawatiTehsil, ChandrapurDistrictS (M.S.), GondwanaGoelMag, 9,1995, 81-90.

[17] A. M. Siddiqui, Fluorosis in Nalgonda district, Hyderbad Deccan, British Med J, 2,1955, 1408.

[18] A. Moudgil, R. N. Srivastava, A. Vasudev, A. Bagga, andA. Gupta, Fluorosis with crippling skeletal deformities, Indian Pediatr, 23,1986, 767-73.

[19] World Health Organization, Fluorides and human health, Monograph Series No. 59. Geneva: World Health Organization., 1970.

[20] M. W. Bilbeissi, C. Fraysee, D. Mitre, M. Kerebel, andB. Kerebel, Dental fluorosis in relation to tea drinking in Jordan, Fluoride, 21,1988, 121-6.

[21] V. Singh, M. K. Gupta, P. Rajwanshi, S. Srivastava, andS. Das, Studies on ingestion of fluoride through tobacco, panmasala and tooth paste, Indian J Environ Hlth, 35, 1993, 215-20.

[22] A. Kubakaddi, P. Bharati, and B. Kasturiba, Effect of fluoride rich food adjuncts and prevalence of fluorosis, J Hum Ecol, 17, 2005, 43-45.

[23] M. K. Malde, R. Gsreiner-Simonsen,K. Jalshamn, and K. Bjorvatn, Tea leaves may release or absorb fluoride depending on the fluoride content of water, Science of the totalenvironment, 366, 2006, 915-917.

[24] A. S. Nirgude, G. S. Saiprasad, P. R. Naik, andS. Mohanty, An epidemiological study on fluorosis in an urban slum area of Nalgonda, Andhra Pradesh, India, Indian J PublicHealth, 54, 2010, 194-6.

[25] E. Ravi Kiran, andK. Vijaya, A study on epidemiology of fluorosis in a village of Nalgonda district, Andhra Pradesh, Nat $J$ Res Com Med, 1, 2012, 123-27.

[26] A. Shashi, M. Kumar, andM. Bhardwaj, Incidence of skeletal deformities in endemic fluorosis, Trop Doct, 38, 2008, $231-33$.

[27] A. K. Gupta, T. P. Singh, P. K. Agarwal, D. Singh, M. Sachan, andV. Agarwal, Quadriparesis - A rare presentation of skeletal fluorosis, JIACM, 9,2008, 201-4.

Table 1 :Fluoride content of drinking water in different villages of study area

\begin{tabular}{cccccc|c|c|}
\hline S.No. & $\begin{array}{c}\text { Name of } \\
\text { villages }\end{array}$ & $\begin{array}{c}\text { Total } \\
\text { population }\end{array}$ & $\begin{array}{c}\text { Total number of } \\
\text { households }\end{array}$ & $\begin{array}{c}\text { Sources of } \\
\text { drinking water }\end{array}$ & $\begin{array}{c}\text { Fluoride range } \\
(\mathrm{mg} / \mathrm{L})\end{array}$ \\
\hline 1 & Pijdura & 915 & 323 & BW and DW & $0.8-2.83$ & Locally grown food \\
2 & Majara & 1347 & 253 & BW and DW & $0.73-0.86 \quad$ Locally grown \\
food & BW and DW & $0.8-0.93$ Locally grown food
\end{tabular}

BW - Bore well, DW - Dug well

Table 2 : Distribution of examinees by age and sex

\begin{tabular}{ccc}
\hline S.No. & Age distribution & Total \\
\hline 1 & $0-14$ yrs & $204(22.29 \%)$ \\
2 & $15-35$ yrs & $368(40.21 \%)$ \\
3 & $36-45$ yrs & $136(14.86 \%)$ \\
4 & $46-60$ yrs & $139(15.19 \%)$ \\
5 & 61 yrs to above & $68(7.43 \%)$
\end{tabular}

\begin{tabular}{cccc}
\hline & Sex distribution & \\
\hline 1 & Male & $468(51.14 \%)$ \\
2 & Female & $447(48.85 \%)$ & $(100 \%)$ \\
\hline & Total & $915 \quad(10)$
\end{tabular}


Figure in parenthesis indicate percentages

Table 3 : Nutrients and fluoride intake through the diets

\begin{tabular}{ccccccc}
\hline S.No. & $\begin{array}{c}\text { Type of } \\
\text { Samples }\end{array}$ & $\begin{array}{c}\text { No of } \\
\text { Samples }\end{array}$ & $\begin{array}{c}\text { Pr(gm/100gm) } \\
\text { Mean }\end{array}$ & $\begin{array}{c}\text { Ca(mg/100gm) } \\
\text { Mean }\end{array}$ & $\begin{array}{c}\text { Vitamin C } \\
(\mathrm{mg} / 100 \mathrm{gm}) \\
\text { Mean }\end{array}$ & $\begin{array}{c}\text { Fluoride } \\
(\mathrm{mg} / 100 \mathrm{gm}) \\
\text { Mean }\end{array}$ \\
\hline 1 & Red gram & 15 & 20.1 & 69 & - & 1.1 \\
2 & Wheat & 13 & 9.8 & 38 & - & 0.2 \\
3 & Sorghum & 9 & 9.9 & 22 & - & 0.8 \\
4 & Soybean & 12 & 40.1 & 218 & - & 0.5 \\
5 & Bengal & 14 & 21 & 53 & - & 1.3 \\
& gram & & & & 6 & 0.5 \\
7 & Red chilly & 11 & 0.9 & 145 & 23 & 0.5 \\
\hline
\end{tabular}

Pr - Protein, $\mathrm{Ca}$ - Calcium

Table 4 : Comparision of foodstuff values to Indian FoodNutrition Chart and Fluoride values with fluoride non endemic area

\begin{tabular}{|c|c|c|c|c|c|c|c|c|c|}
\hline S.No & $\begin{array}{l}\text { Type of } \\
\text { Samples }\end{array}$ & $\begin{array}{c}\operatorname{Pr} \\
(\mathrm{gm} / 100 \mathrm{gm})\end{array}$ & $\begin{array}{c}\text { IFN } \\
\text { C }\end{array}$ & $\begin{array}{c}\mathrm{Ca} \\
(\mathrm{mg} / 100 \mathrm{gm})\end{array}$ & $\begin{array}{c}\text { IFN } \\
\text { C }\end{array}$ & $\begin{array}{c}\text { Vitamin C } \\
(\mathrm{mg} / 100 \mathrm{gm})\end{array}$ & IFNC & $\begin{array}{c}\text { Fluoride } \\
(\mathrm{mg} / \mathrm{L})\end{array}$ & $\begin{array}{l}\text { FNEA } \\
(\mathrm{mg} / \mathrm{L} \\
{ }^{2}\end{array}$ \\
\hline 1 & Red gram & 20.1 & 22.3 & 69 & 73 & - & - & 11.0 & 3.7 \\
\hline 2 & Wheat & 9.8 & 11.8 & 38 & 41 & - & - & 2.40 & 4.6 \\
\hline 3 & Sorghum & 9.9 & 10.4 & 22 & 25 & - & - & 8.22 & - \\
\hline 4 & Soybean & 40.1 & 43.2 & 218 & 240 & - & - & 5.19 & - \\
\hline 5 & Bengalgram & 21 & 20.8 & 53 & 56 & - & - & 2.5 & - \\
\hline 6 & Red chilly & 0.9 & 1.9 & 145 & 160 & - & - & 13.12 & 1.9 \\
\hline 7 & Brinjal & 1.2 & 1.4 & 19 & 18 & 6 & 12 & 4.75 & 1.2 \\
\hline 8 & Tomato & 0.9 & 1.9 & 18 & 20 & 23 & 31 & 4.96 & 3.4 \\
\hline
\end{tabular}

IFNC - Indian Food Nutrition Chart, Pr - Protein, Ca - Calcium, F - Fluoride, FNEA - Fluoride Non Endemic Area

Table 5 : Prevalence of fluorosis in relation to certain dietary substances

\begin{tabular}{|c|c|c|c|c|}
\hline \multirow[t]{2}{*}{ S.No. } & \multirow[t]{2}{*}{ Dietary substance } & \multicolumn{2}{|c|}{ Skeletal fluorosis } & \multirow[t]{2}{*}{ Total } \\
\hline & & Users & Non-users & \\
\hline 1 & Black tea & $61 / 512=(11.91 \%)$ & $15 / 403=(3.72 \%)$ & 76 \\
\hline 2 & Tobacco & $81 / 408=(19.85 \%)$ & $36 / 507=(7.10 \%)$ & 117 \\
\hline & & 142 & 51 & 193 \\
\hline
\end{tabular}

Figures in parenthesis indicate percentage

Table 6 : Clinical symptoms of skeletal fluorosis among fluorotic subjects from study area

\begin{tabular}{|c|c|c|c|c|}
\hline \multirow[t]{2}{*}{ S.No. } & \multirow[t]{2}{*}{ Symptoms } & \multicolumn{3}{|c|}{$\begin{array}{c}\text { Number of } \\
\text { patients / cases }\end{array}$} \\
\hline & & Male & Female & Total \\
\hline 1 & Tingling and numbing of extremities & $13(11.92 \%)$ & $10(11.90 \%)$ & $23(11.91 \%)$ \\
\hline 2 & Joint pain & $42(38.53 \%)$ & $27(32.14 \%)$ & $69(35.75 \%)$ \\
\hline 3 & Back pain & $35(32.11 \%)$ & $21(25 \%)$ & $56(29.01 \%)$ \\
\hline
\end{tabular}


4 Shoulder pain and Neck pain $\quad 17(15.59 \%) \quad 11(13.09 \%) \quad 28(14.50 \%)$

5 Pain in limbs and Stiff limbs

$13(11.92 \%) \quad 9(10.71 \%) \quad 22(11.39 \%)$

6

Stiff vertebral column

$7(6.42 \%) \quad 5(5.95 \%)$

$12(6.21 \%)$

7

Bent/kyphosis

$2(1.83 \%)$

$1(1.19 \%)$

$3(1.55 \%)$

8

Unable to walk properly

$9(8.25 \%)$

$5(5.95 \%)$

$14(7.25 \%)$

9

Bowed legs

Figures in parenthesis indicate percentages

Table 7 : Prevalence of skeletal fluorosis according to age

\begin{tabular}{|c|c|c|c|c|}
\hline S.No. & Age groups (Years) & Skeletal fluorosis & No symptoms & Total \\
\hline 1 & $0-14$ & - & $204(100 \%)$ & $204(100 \%)$ \\
\hline 2 & $15-35$ & $65(17.66 \%)$ & $303(82.33 \%)$ & $368(100 \%)$ \\
\hline 3 & $36-45$ & $36(26.47 \%)$ & $100(73.52 \%)$ & $136(100 \%)$ \\
\hline 4 & $46-60$ & $50(35.97 \%)$ & $89(64.02 \%)$ & $139(100 \%)$ \\
\hline 5 & 61 to above & $42(61.76 \%)$ & $26(38.23 \%)$ & $68(100 \%)$ \\
\hline & Total & $193(21.09 \%)$ & $722(78.90 \%)$ & $915(100 \%)$ \\
\hline
\end{tabular}

Figures in parenthesis indicate percentage, $\chi^{2}=145.59 ; \mathrm{df}=4 ; \mathrm{p}<0.001$

Table 8 : Prevalence of fluorosis according to sex

\begin{tabular}{clccc}
\hline S.No. & Sex & $\begin{array}{c}\text { Prevalence of } \\
\text { skeletal fluorosis }\end{array}$ & No symptoms & Total \\
\hline 1 & Male & $113(24.14 \%)$ & $359(76.70 \%)$ & $468(100 \%)$ \\
2 & Female & $80(17.89 \%)$ & $363(81.20 \%)$ & $447(100 \%)$ \\
\hline
\end{tabular}

Figures in parenthesis indicate percentage, $\quad \chi^{2}=117.48 ; \mathrm{df}=1 ; \mathrm{p}<0.001$ 